\title{
DIFFERENT SOWING METHODS INCREASING THE YIELD AND QUALITY OF SOIL WATER CONSUMPTION OF DRYLAND WINTER WHEAT ON THE LOESS PLATEAU OF CHINA
}

\author{
NoOR, H. - Min, S. ${ }^{*}$ - KHAN, S. - Lin, W - ReN, A. - YU, S. - Ullah, S. - YANG, Z. - GAO, Z. \\ College of Agriculture, Shanxi Agricultural University, Taigu 030801, Shanxi, China \\ *Corresponding author \\ e-mail:sm_sunmin@126.com; phone: +86-354-628-7226 \\ (Received $11^{\text {th }}$ Aug 2020; accepted $28^{\text {th }}$ Oct 2020)
}

\begin{abstract}
A field experiments was conducted at the Agricultural University, Wenxi, Shanxi China. During the winter season of 2017-2019 in which three sowing methods were applied: wide space sowing (WSS), furrow sowing (FS) and drill sowing (DS) along with four nitrogen levels $\left(150 \mathrm{~kg} \cdot \mathrm{hm}^{-1}, 225\right.$ $\mathrm{kg} \cdot \mathrm{hm}^{-1}, 300 \mathrm{~kg} \cdot \mathrm{hm}^{-1}$ and $375 \mathrm{~kg} \cdot \mathrm{hm}^{-1}$ ). The present study was designed to evaluate the effect of tillage condition on nitrogen, production and consumption, protein content/yield and grain yield of dryland wheat. The wide space sowing method has extremely significant effects on the number of ears, thousandgrain weight and yield of winter wheat and also it significantly increased nitrogen absorption efficiency by $50 \%$, nitrogen fertilizer production efficiency by $51 \%$, the number of ears and yield were also significantly increased by $22 \%, 46 \%$ and the content of protein, globulin, gliadin and gluten in grains were the highest in furrow sowing, while the yield of albumin and grain protein were the highest in wide space sowing. The wide space sowing WSS and a nitrogen level of $300 \mathrm{~kg} \cdot \mathrm{hm}^{-1}$ was beneficial to increase water consumption during the growth period, also to increase the tiller dynamics, improve the dry matter quality of the plant, and to improve nitrogen absorption and nitrogen fertilizer production efficiency by increasing grain protein.
\end{abstract}

Keywords: WSS, biomass, leaf ratio, grain yield, grain protein

\section{Introduction}

The dryland winter wheat (Triticum aestivum L.) is the most important crop of the Loess Plateau with approximately 4.3 million hectares cultivating area (Wang et al., 2010). Winter wheat in this region is usually cultivated as a single crop per year followed by more than three months of summer bare fallow. Most of the precipitation (50-60\%) in the Loess Plateau falls in summer from June to September (Zhang et al., 2009). Furthermore, there is a large inter-annual variation in precipitation, such as a wet year may receive two to five times more rainfall than the dry year. Therefore, the production of winter wheat and other crops in the Loess Plateau varies greatly with the distribution pattern and rate of rainfall (He et al., 2014).

Therefore, precipitation stored in the soil during the summer fallow period after wheat harvest is utilized by the subsequent crop and crucial for the success of cropping in the Loess Plateau (Schlegel et al., 2017). Water storage in soil has been affected by the different management practices such as tillage and fertilizer application (Grigoras et al., 2012). Winter wheat yield has been increased by the application of fertilizer but it also resulted in increasing soil water depletion and formation of dry subsoil layer especially in the high land areas (Yan et al., 2015). Hence for sustainable wheat production, it is crucial to seek management practices for improving water-and $\mathrm{N}$-use efficiency (Fu et al., 2014). Improving yield and quality has always been an important task for wheat cultivation. The yield and quality of wheat depends on many factors such as varieties, environment, and cultivation practices (Liang et al., 2019; Xue et al., 2019). 
The wide space and furrow sowing methods, with wide space $(22-25 \mathrm{~cm}$ wide base and $12 \mathrm{~cm}$ height) and furrow by using an all-in-one machine for ridging, fertilization and sowing, is being promoted not only for conserving precipitation and decreasing soil water evaporation, but also for avoiding contamination of soil environment with plastic (Sun et al., 2015; Li et al., 2018). It has been observed that early sowing gives high yield than late sowing due to longer growing period (Munir et al., 2002). The work of sowing method along with the improvement of soil water status and quality, seedling establishment, root growth and crop yield are also being increased mainly through improving water infiltration and retention (Yan et al., 2008). The effect of furrow treatment straw or plastic mulch on maize and wheat crop yields has been persistent (Roelcke et al., 1994).

For dryland wheat production the major task is to use such methods which could effectively enhance the soil moisture consumption. Furrow sowing method has been used for dryland wheat production and results have shown that compared with drill sowing, the furrow sowing can increase the growth of wheat at various growth stages and improve the efficiency of water uptake and increase yield. Kumar et al. (2011) and Dong et al. (2018) showed that compared with flat field sowing, the use of furrow sowing in dryland wheat could increase stem height, extend the duration of functional green leaves, increase spike quality, and increase yield by 53\%. Yue et al., 2006 showed that compared with flat sowing, soil moisture is not easily lost and water retention in soil is higher under furrow sowing. With furrows, the surface temperature of $0-5 \mathrm{~cm}$ cultivated soil layer is increased by $1-2{ }^{\circ} \mathrm{C}$ (Yue et al., 2006). The work of sowing method along with the improvement of soil water status and quality, seedling establishment, quality and crop yield can also be increased mainly through improving water infiltration and retention (Yan et al., 2008). The tiller number and percentage of productive tillers, leaf area index, dry weight, and yield were increased by DS without decline in grain protein. Furthermore, it also enhanced the $\mathrm{N}$ use efficiency in wheat (Liu et al., 2018).

Fertilizers constitute an integral part for improved crop production technology. Nitrogen $(\mathrm{N})$ is an essential mineral nutrient for plant growth, expands soil fertility and crop productivity (López et al., 2012; Wang et al., 2012). Proper amount of $\mathrm{N}$ fertilizer application is considered a key for high crop production (Liang et al., 2019). Increase in grain yield is often associated with low protein content (Triboi et al., 2002). Applying N fertilizer promotes wheat root elongation and increase soil water consumption, it also promotes wheat plant growth and then significantly improve wheat yield and water use efficiency. Grain protein content was also affected by the soil moisture content and decreased in the year with low precipitation, while increased in the year with high precipitation (Sun et al., 2014). The yield of these two crops was compared with that of conventional cultivation methods may be due to ideal coordination between soils humidity and temperature ( $\mathrm{Li}$ et al., 2013).

On the other hand, rainfall accounts for $25-40 \%$ of the water requirement for winter wheat growth and cannot meet its full demand (Ahmadzai et al., 2017). Available water and nitrogen $(\mathrm{N})$ are considered the most limiting factors in wheat production in most parts of the world, especially in arid and semi-arid regions (Gonzalez et al., 2010). Supplemental irrigation and Nitrogen fertilizer application are required to match soil water stress and stabilize yields (Tavakkoli et al., 2004). The highest Nitrogen uptake in the growth period occurred from reviving stage to anthesis stage. The proportion of Nitrogen accumulated in leaf and stem was high before the anthesis stage and the accumulated nitrogen rate in stem reached peak at the anthesis stage (Zhao et al., 2006). 
Recent technological advances have focused on the simultaneous and synergistic improvement of several factors including water use, nitrogen efficiency, yield, and grain quality (Parry et al., 2011). The presence of compacted soil above and loose soil below not only prevents air leakage but also reduces water evaporation. The tridimensional sowing pattern is known (Zhao et al., 2016). Sowing methods influenced wheat yield due to changes in soil water storage and water-use efficiency on the Loess Plateau in China. However, it remained unclear how different sowing methods would influence soil bacterial diversity and abundance that contribute to the changes in soil quality and micro-environment (Mann et al., 2019).

The objective of this study was to find the best sowing method of nitrogen level to increase the yield and quality of winter wheat crop. Wide space sowing (WSS) with a nitrogen level of $300 \mathrm{~kg} \cdot \mathrm{hm}^{-1}$ enhances dry matter accumulation, to achieve high yield in addition, it was showed that improved, which was beneficial to the improvement of nitrogen uptake at different growing stages, ultimately improving quality, increasing yield and grain protein content.

\section{Materials and methods}

\section{Experimental site and meteorological condition}

Field experiment was conducted during the winter wheat growing season from 2017 to 2019 at the experimental station of Shanxi Agricultural University. The experimental area was geographically located in Wenxi $\left(35^{\circ} 200 \mathrm{~N}, 111^{\circ} 170 \mathrm{E}\right)$, Shanxi Province, China. It was semi-arid, hilly, dryland area where precipitation was the sole source of moisture with an average annual rainfall of $450-630 \mathrm{~mm}, 60-70 \%$ of precipitation of the year was concentrated in July-September. This region is characterized by semiarid climate which receives $491 \mathrm{~mm}$ of average annual precipitation, $12.9^{\circ} \mathrm{C}$ annual mean temperature, and $2242 \mathrm{~h}$ of annual sunshine. The soil in the test site belongs to calcareous cinnamon soil according to the Chinese soil classification standard (Table 1). The basic nutrient properties of soil from 0-20 $\mathrm{cm}$ depth were determined and presented in Table 1, the $\mathrm{pH}$ of the soil was 7.93.

Table 1. Soil nutrient properties from experimental location Wenxi

\begin{tabular}{c|c|c|c|c}
\hline Year & $\begin{array}{c}\text { Organic matter } \\
\left(\mathbf{g}^{\cdot} \mathbf{k g}^{-1}\right)\end{array}$ & $\begin{array}{c}\text { Alkaline N } \\
\left(\mathbf{m g} \cdot \mathbf{k g}^{-\mathbf{1}}\right)\end{array}$ & $\begin{array}{c}\text { Available P } \\
\left(\mathbf{m g} \cdot \mathbf{k g}^{-1}\right)\end{array}$ & $\begin{array}{c}\text { Available K } \\
\left(\mathbf{m g} \cdot \mathbf{k g}^{-\mathbf{1}} \mathbf{)}\right.\end{array}$ \\
\hline $2017-2018$ & 12.61 & 44.07 & 10.71 & 188.87 \\
$2018-2019$ & 8.93 & 40.05 & 14.16 & 200.24 \\
\hline
\end{tabular}

\section{Precipitation and temperature $\left({ }^{\circ} \mathrm{C}\right)$ distribution}

The annual precipitation during 2015-2016 and 2016-2017 was $59.7 \mathrm{~mm}$ and $40.2 \mathrm{~mm}$, which is less than the average long-term precipitation. In 2014-2015, most of the precipitation occurred during the fallow season with $97.2 \mathrm{~mm}$ higher than the longterm precipitation. In 2015-2016, total precipitation was $416.6 \mathrm{~mm}$, and precipitation during growth was $198.3 \mathrm{~mm}$, In 2017-2018 wintering stage precipitation was $152.40 \%$, The precipitation during the growing seasons of winter wheat during 2016-2019 at the experimental site were $240.9 \mathrm{~mm}, 218.3 \mathrm{~mm}$ and $68.9 \mathrm{~mm}$. Precipitation from sowing to wintering and jointing to maturity were abundant. The yearly average in the last 35 years (1981-2016) was $490.90 \mathrm{~mm}$. Based on the generalized precipitation classification 
(Ren et al., 2019), the annual precipitation pattern is divided into three types: dry year $(\mathrm{P} \leq 25 \%)$, normal year $(25 \%<\mathrm{P}<25 \%)$ and wet year $(\mathrm{P} \geq 25 \%)$. The $\mathrm{P}$ was calculated as follows:

$$
\mathrm{P}=(\text { the year average precipitation }-490.90) / 490.90
$$

Temperature values $\left({ }^{\circ} \mathrm{C}\right)$ in the fallow period and growth stage from 2012 to 2013. Were 24.9, and 10.4, respectively, from 2013-2014 the values were 26.7, and 10.7, respectively, from 2014-2015 the values were 24.8 and 10.5, respectively, from 20152016 the values were 24.7 and 10.0 , respectively. The detailed temperature values $\left({ }^{\circ} \mathrm{C}\right)$ are given in Figure 1.

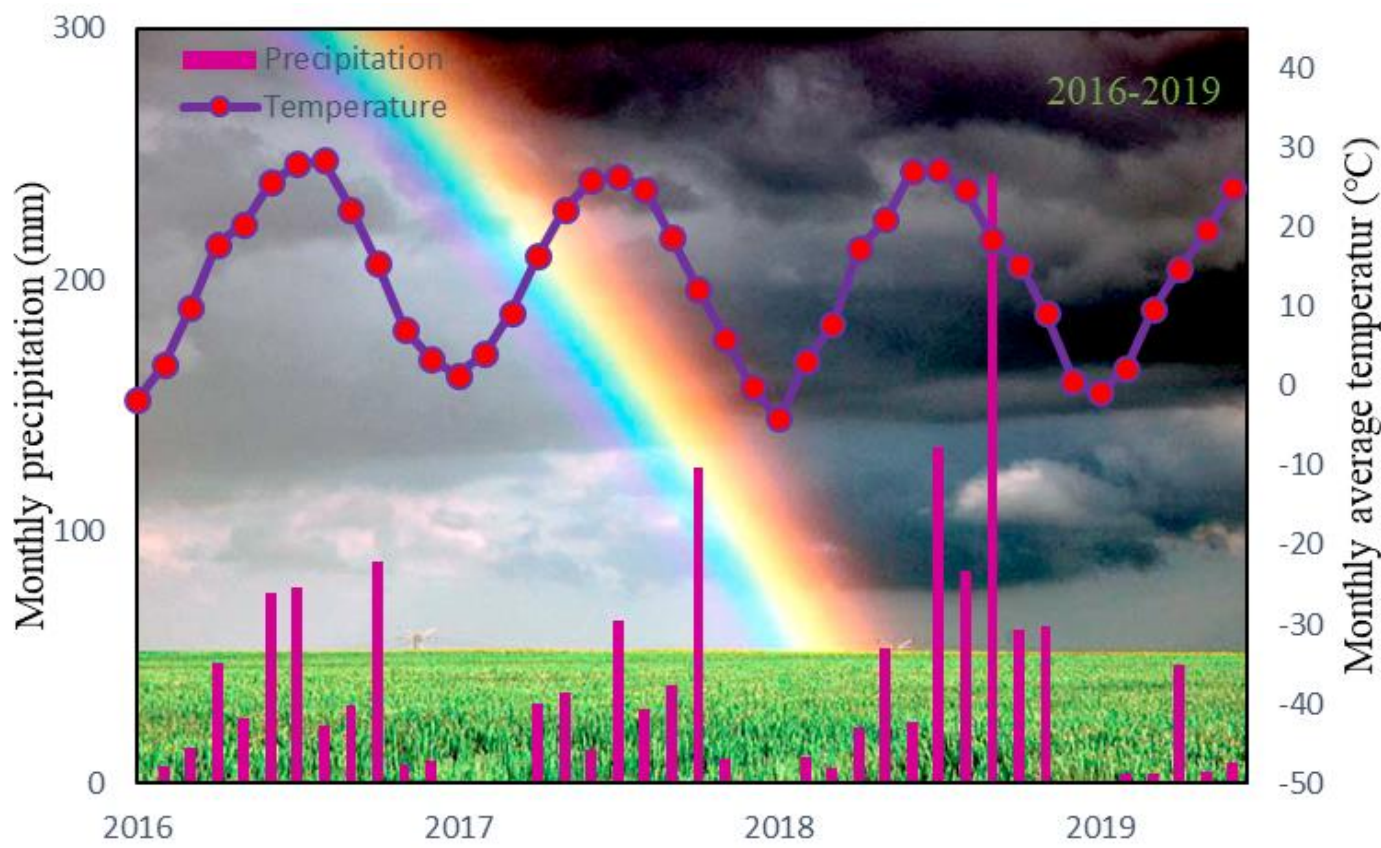

Figure 1. Precipitation and mean temperature during the fallow period in the study year (20162019) in different growth stages of wheat at the experimental site in Wenxi, China. Fallow period: (22 June - 30 September), sowing to wintering (1 October - 30 November), wintering to jointing (1 December - 10 April), jointing to anthesis (11 April - 10 May), and anthesis to maturity (22 May - 10 June). (Source: Meteorological Observation of Wenxi County, Shanxi Province, China)

\section{Experimental design and treatments}

\section{Field management and experimental design}

An experiment was started with the winter wheat season of October 2017, and ended after the winter wheat was harvested in ${ }^{15}$ June 2019, covering 2 successive wheat crops at the same experimental plot. The seeds of winter wheat (Triticum aestivum L.) cultivar 'Yunhan 20410', were obtained from Wenxi Agriculture. Wheat stubble of 20-30 cm from the previous wheat crop was left in field to reduce evaporation and to increase organic carbon content in the soil. The experiment was set as split-plot design with a single-factor completely randomized design. Experiment comprised of three different sowing methods: wide space sowing (WS), furrow sowing (FS) and drill sowing (DS). 
The area of each plot was $40 \mathrm{~m}^{2}(5 \mathrm{~m} \times 8 \mathrm{~m})$ and each treatment was repeated 3 times. The details of the machinery and sowing techniques are given in Figures 2 and 3. After the harvest of the former corn four nitrogen levels $\left(150 \mathrm{~kg} \cdot \mathrm{hm}^{-1}, 225 \mathrm{~kg} \cdot \mathrm{hm}^{-1}, 300\right.$ $\mathrm{kg} \cdot \mathrm{hm}^{-1}, 375 \mathrm{~kg} \cdot \mathrm{hm}^{-1}$ ) were applied. Before planting, $150 \mathrm{~kg} \mathrm{~N} \mathrm{hm}{ }^{-1}$ (Urea, $46 \%$ ), $\mathrm{P}_{2} \mathrm{O}_{5}$ $\left(38 \mathrm{~kg} \mathrm{ha}^{-1}\right)$ and $\mathrm{K}_{2} \mathrm{O}\left(75 \mathrm{~kg} \mathrm{ha}^{-1}\right)$ were broadcasted evenly on the surface of plots. There was no top dressing during the growing seasons. The plot area was $30 \mathrm{~m}^{2}(5 \mathrm{~m} \times$ $6 \mathrm{~m})$. The planting density was $315 \times 10^{4}$ plant $\mathrm{ha}^{-1}$ and each treatment was repeated 3 times. The straw was returned to the field after the previous stubble corn was harvested and planted on the October, 2018. Weeds and pests were well controlled by hand and no irrigation was applied across the two experimental years.

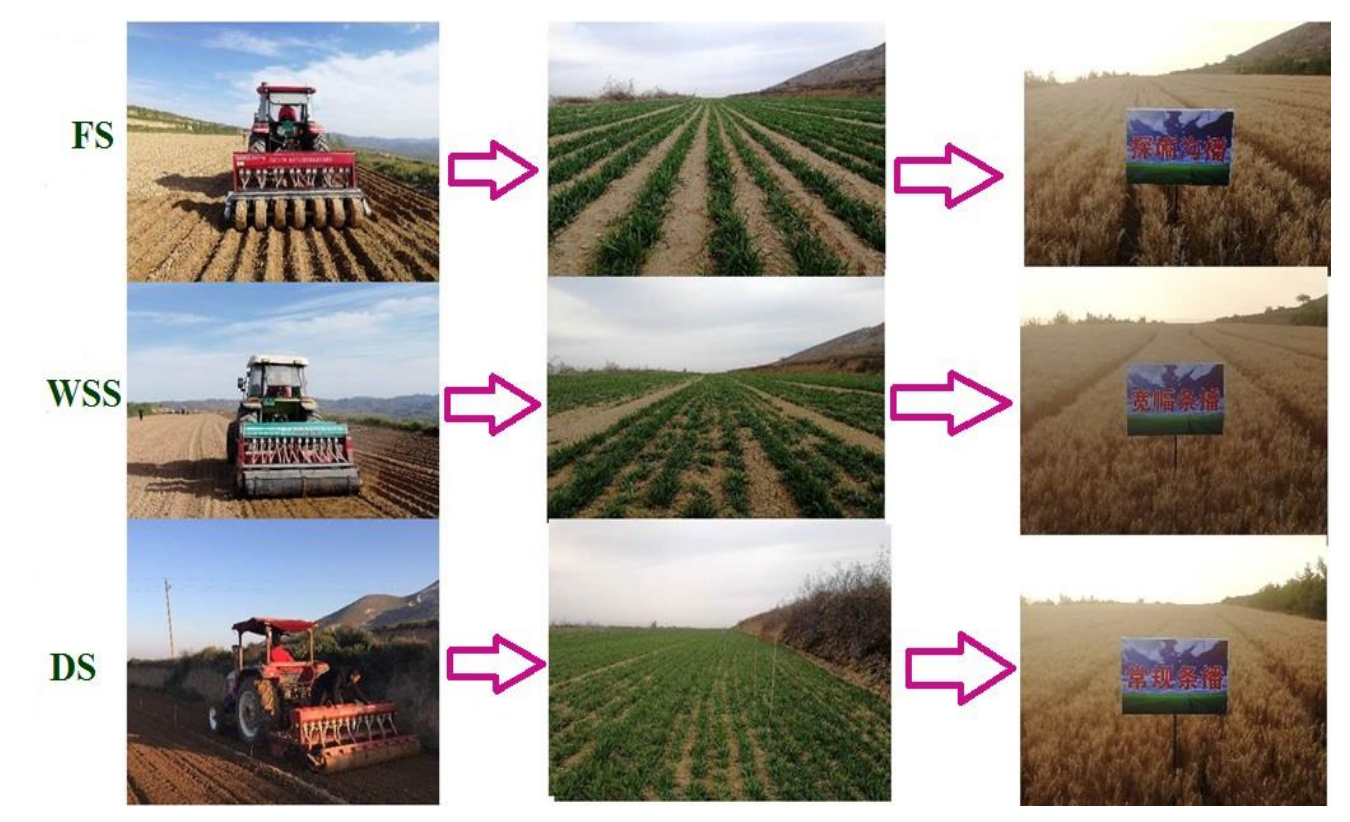

Figure 2. (a) Furrow sowing (FS), (b) wide space sowing (WSS), (c) drill sowing (DS)

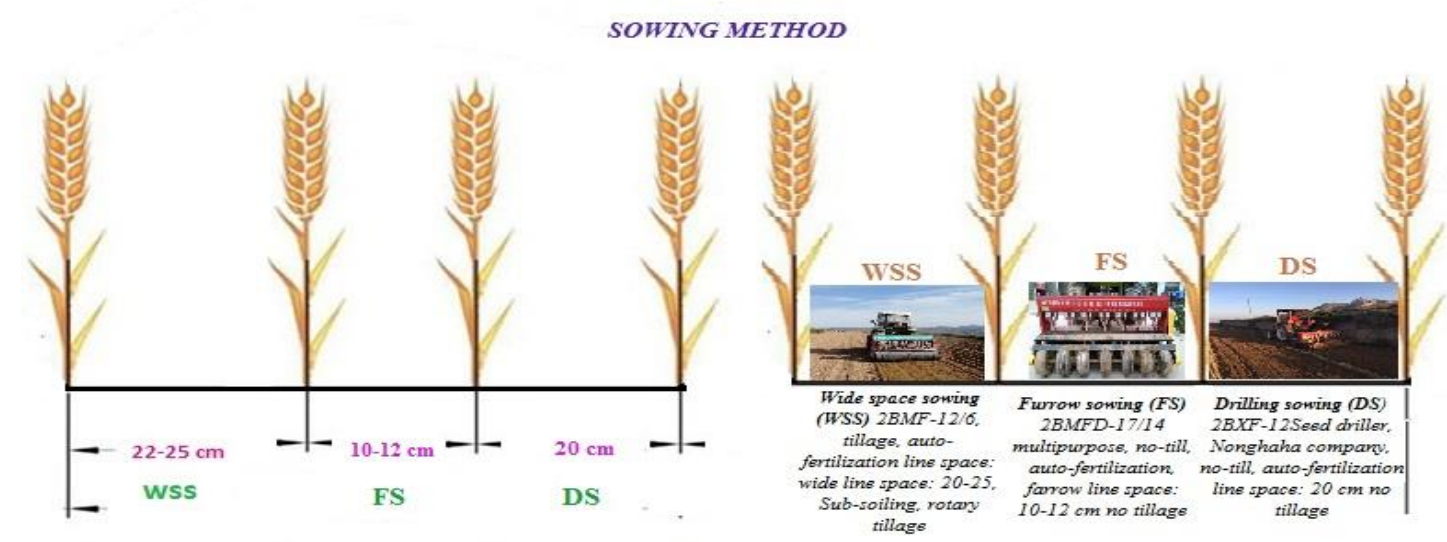

Figure 3. Crop arrangement of wheat in configurations with different sowing methods, wide space sowing (WSS), furrow sowing (FS), drill sowing (DS) 


\section{Measurements}

\section{Soil water storage}

A soil sample of 0-200 $\mathrm{cm}$ (each $20 \mathrm{~cm}$ was a soil layer) was drilled at each growth stage and the soil moisture was measured after drying. Due to the flat terrain the groundwater depth below $15 \mathrm{~m}$ and the precipitation infiltration depth not exceeding $2 \mathrm{~m}$, the surface runoff groundwater recharge and apparent depth leakage are all zero. Soil water storage were calculated by using the following formula (Liang et al., 2019):

$$
\begin{aligned}
& \text { Soil water storage }(\mathrm{mm})=[\text { (wet soil weight }- \text { dry soil weight }) / \\
& \text { dry soil weight } \times 100 \%] \times \text { soil thickness } \times \text { soil bulk density }
\end{aligned}
$$

Changes in soil water storage ( $\triangle \mathrm{SWS}$ ) for a specific stage of wheat is calculated as the difference between the soil water storage at the beginning (SWS1) and end of the growth stage (SWS2) as follows:

$$
\Delta \mathrm{SWS}=\mathrm{SWS} 1-\mathrm{SWS} 2
$$

The water consumption ( $\mathrm{CA}, \mathrm{mm})$, percentage of $\mathrm{CA}$ to total water consumption $(\mathrm{CP}, \%)$, and daily water consumption $(\mathrm{CD}, \mathrm{mm})$ were calculated as follows:

$$
\begin{gathered}
\mathrm{CA}=\mathrm{P}+\mathrm{I}-\Delta \mathrm{SWS} \\
\mathrm{CP}=\mathrm{CAG} / \mathrm{CA} \\
\mathrm{CD}=\text { the } \mathrm{CAG} / \mathrm{d}
\end{gathered}
$$

where $\mathrm{P}$ is precipitation ( $\mathrm{mm}$ ) during this period, $\mathrm{I}$ is the irrigation amount, CAG refers to water consumption at a certain stage, and $\mathrm{d}$ is the number of days in the growing stage.

$$
\mathrm{WUE}=\mathrm{Y} / \mathrm{ET}
$$

where WUE is water use efficiency $\left(\mathrm{kg} \mathrm{h}^{-1} \mathrm{~mm}^{-1}\right)$; $\mathrm{Y}$ is the yield of wheat $\left(\mathrm{kg} \mathrm{h}^{-1}\right)$.

\section{Determination of spike number}

Comparison of the spike of interest with the model spike occurs in an n-dimensional vector space, which dimensions are defined by the total spikelet number of the spike of interest. The geometrical difference in GYDAS between the two spikes is based on the scalar product of these two vectors and were calculated by using the following formula (Noor et al., 2020):

$$
\cos 4(\vec{a}, \vec{b})=\frac{\vec{a} \cdot \vec{b}}{|\vec{a}| \cdot|\vec{b}|}
$$

\section{Nitrogen use efficiency (NUE)}

At maturity, the total $\mathrm{N}$ concentration in the aboveground tissue was determined by $\mathrm{H}_{2} \mathrm{SO}_{4}-\mathrm{H}_{2} \mathrm{O}_{2}$ digestion and analysis of the digestate by the automatic Kjeldahl 
method (FOSS8400, Foss, Hilleroed, Switzerland). The N accumulation (NA) was calculated as the product of $\mathrm{N}$ concentration and aboveground biomass. The $\mathrm{N}$ uptake efficiency (NUE) was calculated as the ratio of $\mathrm{N}$ uptake by the aboveground crop at maturity to the amount of $\mathrm{N}$ fertilizer applied. The $\mathrm{N}$ fertilizer productivity (NFP) was calculated as the ratio of the grain yield to the amount of $\mathrm{N}$ fertilizer applied. NUE was calculated as the ratio of the grain yield to the total $\mathrm{N}$ uptake (Guo et al., 2014).

\section{Determination of plant agronomic traits}

Three rows of wheat plants within $0.667 \mathrm{~m} 2$ of a fixed point were taken at each growth stage to investigate the number of stems in the population. Plant height and leaf area of 20 plants with sowing growth and representativeness were taken at each growth stage and the plant height was measured; at the same time the length, width and number of green leaves of the second leaf were measured. Leaf area index for the determination of leaf area, the length and width of the second leaf and total number of leaves were calculated. Leaf area was measured using the following formula (Noor et al., 2020):

\section{Leaf area $=$ length $\times$ width $\times$ number of green leaves $\times 0.85$}

where 0.85 was the adjustment factor. Then leaf area index (LAI) was calculated by dividing the leaf area $\left(\mathrm{cm}^{2}\right)$ by the ground surface area.

\section{Grain to leaf area ratio}

Grain to leaf ratio was calculated according to Feng et al. (1999), using Equations 9 and 10 :

$$
\begin{aligned}
& \text { Grain number to leaf area ratio }=\frac{\text { total number of grain per unitarea }}{\text { total leaf area on the same plot at booting stage }} \\
& \text { Grain weight to leaf ratio }=\frac{\text { grain weight }(\mathrm{mg}) \text { per unit area }}{\text { total leaf area on the same plotat booting stage }}
\end{aligned}
$$

Total leaf area was taken from the same plot at booting stage $\left(\mathrm{cm}^{2}\right)$.

At maturity period 30 ears were burned at $105{ }^{\circ} \mathrm{C}$ for $30 \mathrm{~min}$, dried at $80{ }^{\circ} \mathrm{C}$ to constant weight, crushed with a DE-100 g mini high-speed universal grinder produced (Zhejiang Hongjingtian Industry and Trade Co., Ltd) and using a continuous extraction method to determine the protein content of the grains. The MJZ-II type gluten index tester was used to determine the wet gluten content and the micro dough LAB 2800 micro flour analyzer was used to determine the flour characteristics.

\section{Grain yield, grain protein yield}

At maturity, plants were randomly sampled from three $1 \mathrm{~m}^{2}$ areas from each plot to determine grain number spike ${ }^{-1}$ and 1,000 grain weight. All plants from the plots were harvested on the 16th June 2018, and the 15th June 2019. Grains were air-dried whereas aboveground plant parts were oven dried until constant weight to determine the grain yield $\left(\mathrm{kg} \mathrm{ha}^{-1}\right)$ and dry biomass. The harvest index $(\mathrm{HI})$ was calculated dividing the grain yield by the aboveground dry biomass. 


\section{Statistical analysis}

Two-way analysis of variance (ANOVA) was performed to determine the significance of sowing methods, statistical analysis was carried out using DPS 7.05 software and the significant difference among treatments were calculated by least significant difference test (LSD) at the significance level of $p \leq 0.05$. Pearsons correlation coefficients were calculated in order to determine the relationship between water consumption and yield.

\section{Results}

\section{Production and composition yield quality formation}

The effect of sowing methods on production and composition yield quality formation of winter wheat can be seen from Figure 4. Compared with $(D S)$ the number of spikes, thousand seed weight and yield under wide space sowing, and even sowing increased from 2017 to 2019. From 2017 to 2018 the number of ears increased by $22 \% 16 \%$ and $17 \%$, from 2018 to 2019 it increased by $46 \% 16 \%$ and $32 \%$ and the differences between the treatments were significant with WSS being the highest. The thousand grain weight increased by $3 \% 7 \%$ and $4 \%$, respectively. The difference between the treatments was not significant and it increased by $2 \%, 5 \%$ and $0 \%$ respectively and the highest was the trench sowing followed by the WSS, the difference between $D S$ was not significant; Compared with DS the number of panicles for WSS increased from 2017-2018 by $25 \%$ $17 \%$ and $11 \%$, and in $2018-2019$, it increased by $55 \% 22 \%$ and $40 \%$, respectively and the differences between the treatments were significant.

\section{Effects of different sowing methods on growth and development of population dynamics at each stage characteristics of winter wheat}

Development population dynamics at each stage characteristics of winter wheat, the number of tillers in each growth period increased then decreased and reached the maximum at the jointing stage (Fig. 5). The tiller number of drill group was higher in the early and middle stage, but lower in the late stage than in other sowing methods. In different growth periods, compared with drill, the tiller number of the population under wide drill increased by $6 \%, 27 \%, 9 \%$ and $22 \%$, respectively and was higher than in other sowing methods. The tiller number of the population under FS in the flowering stage and maturity stage increased by $3 \%$ and $16 \%$, respectively compared with that under $D S$. The number of tillers in the mature stage increased by $7 \%$. WSS can promote the tiller process in different growth periods, especially in the jointing period, the effect was more significant, followed by the $F S$ effect, mainly increasing the number of tillers in the mature period (Fig. 5). That during the wintering maturity period the number of tillers in the population first increased then decreased and then decreased slowly and the number of tillers in the jointing period reached the highest value. Compared with $D S$ the number of tillers in the wide wintering maturity stage increased by $34 \%, 11 \%, 25 \%$, $40 \%$, and $46 \%$, respectively and the jointing maturity period was significantly higher than in other sowing methods. The tiller number of the population at the growing stage was increased by $5 \%, 8 \%, 12 \%, 13 \%$ and $16 \%$, mature stages were increased by $48 \%$, $18 \%, 26 \%$ and $32 \%$. It can be seen that WSS can increase the number of tillers in each period. 

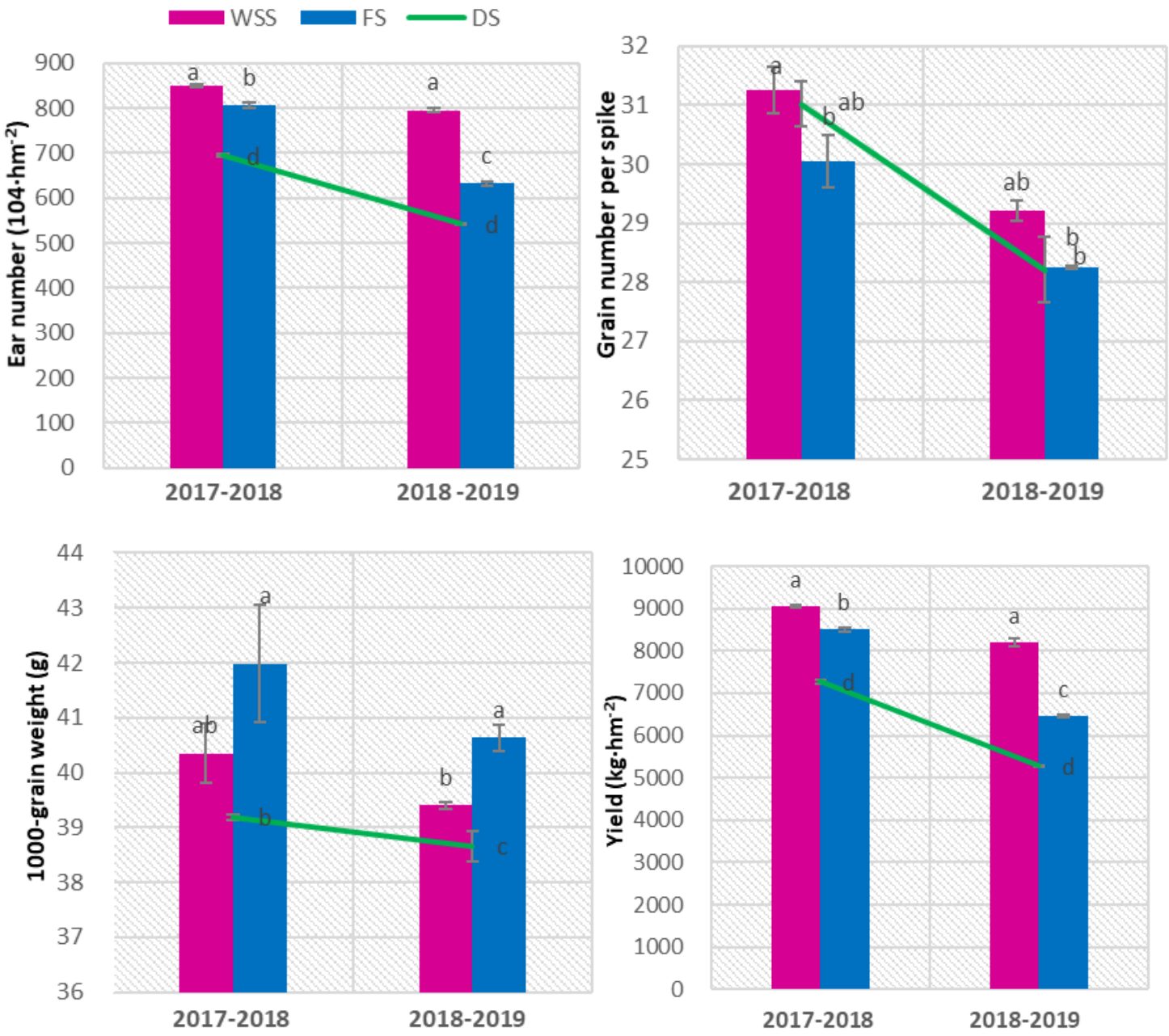

Figure 4. Effects of different sowing methods on yield and components of WSS; wide space sowing; FS: furrow sowing; DS: drilling sowing; winter wheat. Different letters indicate significant difference among treatments at the significance level of $p \leq 0.05$

\section{Effect of different sowing methods on plant height and leaf area index at different growth stages}

Effects of different sowing methods on plant height were observed at different growth periods (Fig. 6). From 2017-2018 no significant differences were observed between sowing methods at the wintering and jointing stages, in wintering, jointing and booting stage, the plant height was maximum at FS flowering and maturity stage, the plant height was higher in DS than FS. Leaf area index (LAI) in each growth period increased and then decreased, reaching the maximum at booting stage. At different growth stages, the leaf area index of WS was higher than in other sowing methods, and increased as compared with DS. Sowing methods especially WS improved LAI and the effect was more significant at the later growth stage. From 2018-2019 with the progress of fertility the plant height under different sowing methods showed a trend of rising first and then gradually flattening. The plant height of each sowing stage was higher than that of other sowing methods. The plant height of WSS was higher than that of FS and DS. It can be seen that different planting methods can increase plant height and WSS has the best effect. Leaf area 
index (LAI) first shows a trend of increase and then decrease and the difference between booting and maturity is obvious. During the booting and maturity stage the leaf area under WSS was significantly higher than in other sowing methods the leaf area was significantly higher than that of FS and DS and the leaf area under FS was significantly higher than that of DS. It can be seen that different sowing methods could increase the leaf area of winter wheat at the later growing stage and wide space sowing was better followed by even sowing.
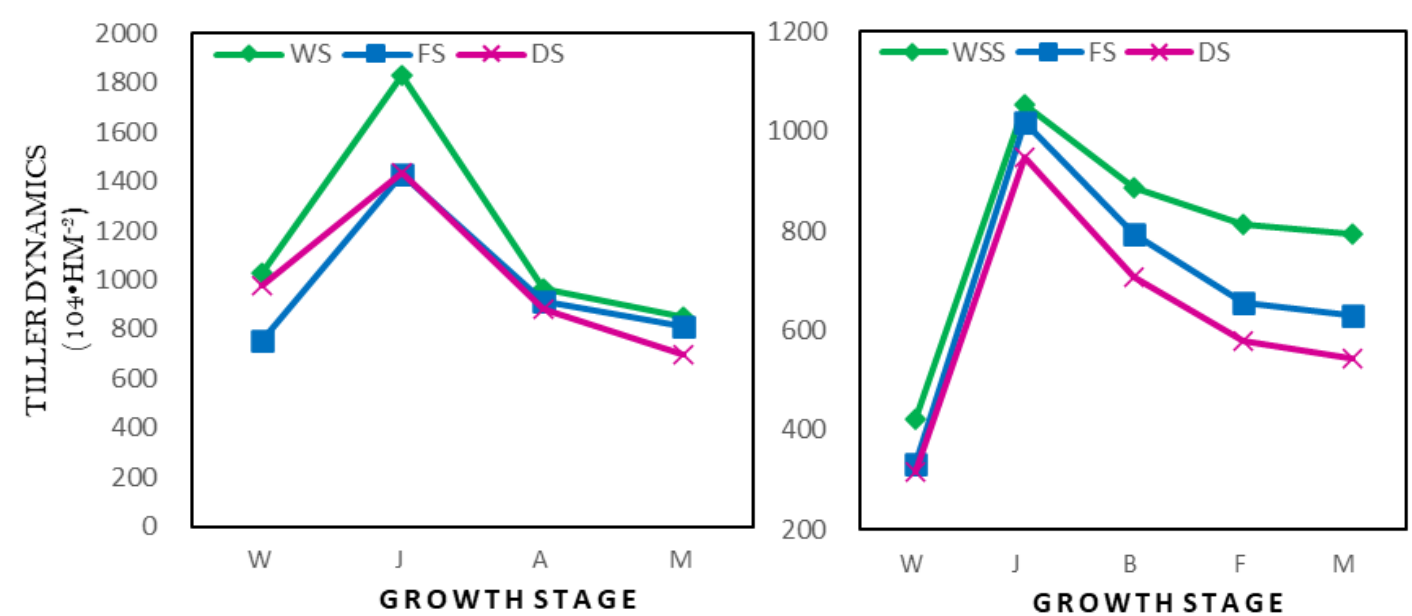

Figure 5. Effect of sowing method on tiller dynamics at different growth stages of winter wheat. $W, J, B, F, A$, and $M$ indicate wintering, jointing, bolting, Flowering, anthesis, and maturity stages W-J: Wintering stage to jointing stage, Oct 1 to Apr 10; J-B: Jointing stage to Booting, Apr 11 to May 10; B-A. Booting stage to anthesis, May 11 to May 21; A-M: Anthesis to maturity and flowering to maturity may 22 to Jun 10. Different letters indicate significant difference among treatments at the significance level of $p \leq 0.05$

\section{Effects on soil water consumption}

The water consumption and water storage consumption ratio in the growth period under wide space sowing and drill sowing were significantly increased, while the water consumption ratio of precipitation and irrigation water consumption ratio were significantly reduced as can be seen from Table 2. Compared with drill sowing, the water consumption and water storage consumption ratio of furrow sowing $(F S)$ and even sowing during the growth period were significantly increased, while the water consumption ratio of precipitation and irrigation water consumption ratio were significantly reduced, while water consumption of precipitation and irrigation decreased, but there was no significant difference between the two treatments. It can be seen that wide space sowing (WSS) and drill sowing $(D S)$ can increase the water consumption and water storage consumption ratio significantly during the growth period and reduce the water consumption ratio of precipitation and irrigation water consumption ratio development of winter wheat. 

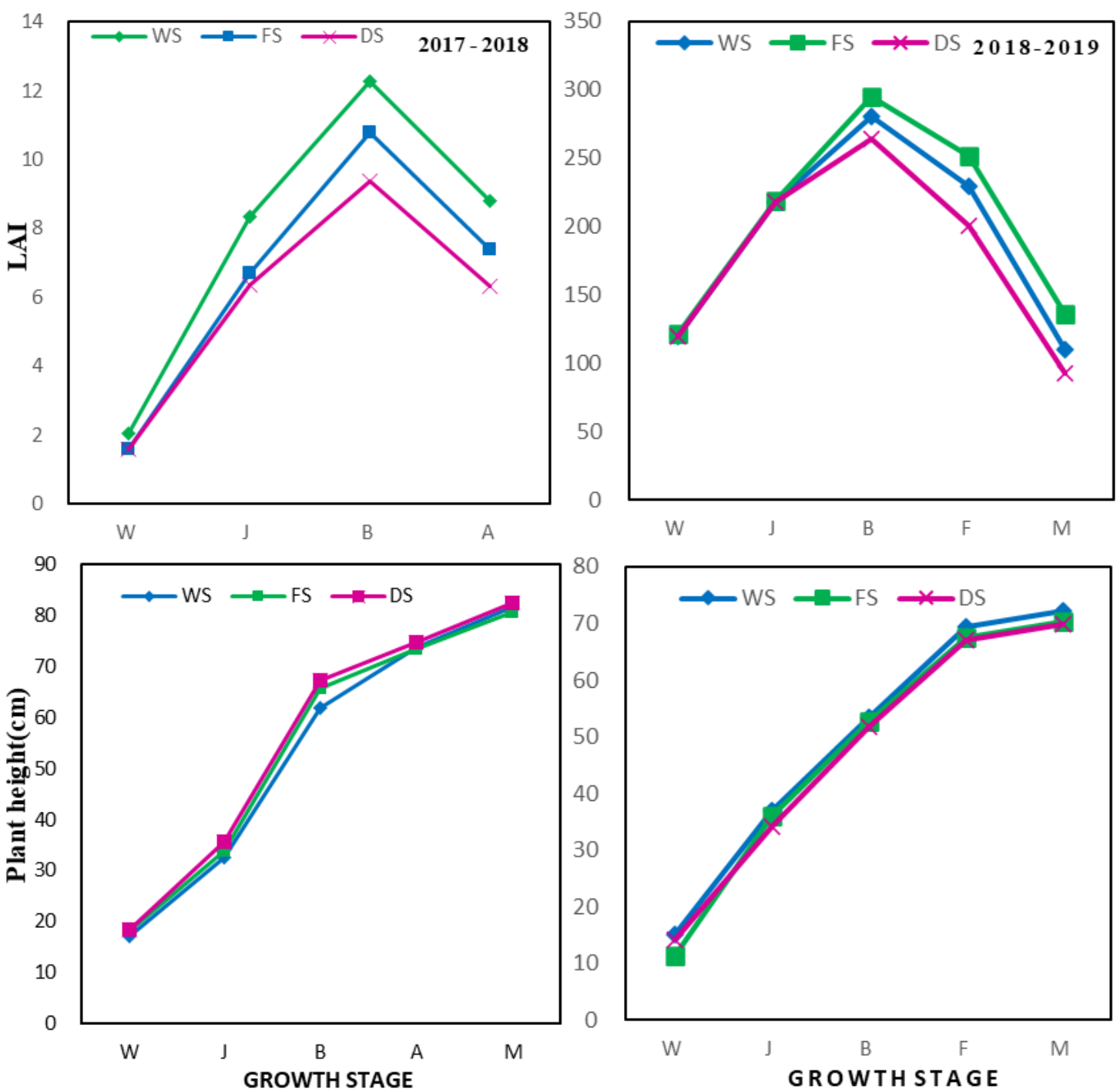

Figure 6. Effect of sowing method on plant height and leaf area index (LAI) at different growth stages of winter wheat. $W, J, B, F, A$, and $M$ indicate wintering, jointing, bolting, Flowering, anthesis, and maturity stages; WS: wide space sowing; FS: furrow sowing; DS: drilling sowing; $W-J$ : Wintering stage to jointing stage, Oct 1 to Apr 10; J-B: Jointing stage to Booting, Apr 11 to May 10; B-A: Booting stage to anthesis, May 11 to May 21; A-M: Anthesis to maturity and flowering to maturity may 22 to Jun 10. Different letters indicate significant difference among

treatments at the significance level of $p \leq 0.05$

\section{Effects on the proportion of soil water consumption in different growth stages}

As can be seen from Table 3, water consumption ratio of the soil in the $0-200 \mathrm{~cm}$ soil layer during wintering jointing stage and flowering maturity stage was higher than that during sowing wintering stage and jointing flowering stage. Compared with drill sowing the water consumption ratio of $0-200 \mathrm{~cm}$ soil layer increased during the period of wintering and maturity under wide drill sowing, it was significantly higher in wintering and jointing period than in other sowing methods. During the sowing and wintering stage, the water consumption ratio of the soil in the $0-200 \mathrm{~cm}$ soil layer was the highest followed by $F S$, wide and drill. During the winter jointing stage, followed by $F S$ the 
wide and drill sowing was the highest and followed by WS flowering and maturity, furrow sowing was the highest. Wide and drill sowing can increase the proportion of water consumption in the soil layer of $0-200 \mathrm{~cm}$ during the wintering period and the jointing stage, which was conducive to the vegetative growth and reproductive growth of winter wheat.

Table 2. Effects of sowing method on soil water consumption ratio of 0-200 cm depth from different water for winter wheat

\begin{tabular}{c|c|c|c|c}
\hline $\begin{array}{c}\text { Sowing } \\
\text { method }\end{array}$ & $\begin{array}{c}\text { Soil water consumption in } \\
\text { the growing stage }(\mathbf{m m})\end{array}$ & $\begin{array}{c}\text { Soil water } \\
\text { consumption ratio }(\%)\end{array}$ & $\begin{array}{c}\text { Precipitation } \\
\text { consumption ratio (\%) }\end{array}$ & $\begin{array}{c}\text { Irrigation } \\
\text { consumption ratio (\%) }\end{array}$ \\
\hline WSS & $435.67 \mathrm{a}$ & $36.12_{\mathrm{a}}$ & $50.11_{\mathrm{c}}$ & $13.77_{\mathrm{c}}$ \\
FS & $410.78_{\mathrm{b}}$ & $32.25 \mathrm{~b}$ & $53.15_{\mathrm{b}}$ & $14.61_{\mathrm{b}}$ \\
DS & $372.42_{\mathrm{c}}$ & $25.27_{\mathrm{c}}$ & $58.62 \mathrm{a}$ & $16.11_{\mathrm{a}}$ \\
\hline
\end{tabular}

Table 3. Effects of sowing method on soil water consumption ratio of 0-200 cm depth at different growing stage for winter wheat

\begin{tabular}{c|c|c|c|c}
\hline Sowing method & W & J & A & M \\
\hline WSS & $11.60_{\mathrm{d}}$ & $40.32_{\mathrm{a}}$ & $15.61_{\mathrm{b}}$ & $32.47_{\mathrm{c}}$ \\
FS & $18.03_{\mathrm{b}}$ & $24.06_{\mathrm{b}}$ & $13.01_{\mathrm{c}}$ & $44.91_{\mathrm{a}}$ \\
DS & $14.76_{\mathrm{c}}$ & $29.75_{\mathrm{c}}$ & $15.19_{\mathrm{b}}$ & $40.30_{\mathrm{b}}$ \\
\hline
\end{tabular}

Sowing rates on water content in $0-200 \mathrm{~cm}$ soil layer at different growth stages of dryland wheat. $\mathrm{W}, \mathrm{J}$, $\mathrm{A}$, and $\mathrm{M}$ indicate, $(\mathrm{W})$, wintering, $(\mathrm{J})$, jointing, $(\mathrm{A})$, anthesis, and $(\mathrm{M})$, maturity stages; WS: wide space sowing; FS: furrow sowing; DS: drilling sowing; W-J: WS: wide space sowing; FS: furrow sowing; DS: drilling sowing

\section{Effects on nitrogen operation before flowering and nitrogen accumulation after flowering}

Nitrogen accumulation after flowering can be seen from Table 4. Compared with drill sowing (DS) 2017-2018, the operation amount of nitrogen accumulation before flowering was significantly increased by $74 \%, 44 \%$ and $66 \%$, respectively. The contribution rate of operation of nitrogen accumulation before flowering to grains was $72.58 \%$ and the operation rate of wide drill sowing was $69.03 \%$, higher than that of groove sowing and drill sowing. Compared with drill sowing, the nitrogen accumulation after flowering was significantly increased by $76 \%, 52 \%$ and $39 \%$, respectively. It can be seen that different sowing methods mainly promote the operation of nitrogen accumulation before flowering to increase the contribution rate to grains, among which WSS was better than other methods. In 2018-2019 compared with the drilling, drill and wide before flowering of nitrogen accumulation amount of operation and contribution rate on the grain were significantly increased, among them, the accumulation of nitrogen run before flowering amount increased by $35 \%, 16 \%$ and $11 \%$, respectively. For the grain the contribution rate increased by $10 \%, 4 \%$ and $4 \%$ respectively and contributed to wide and drilling of grain most significantly. Compared with drill sowing, the nitrogen accumulation after flowering was reduced under the treatments of wide sowing drill sowing, furrow sowing, but there was no significant difference between the treatments of $F S$ and $D S$. The contribution rate of nitrogen accumulation to kernels decreased significantly after flowering, which shows that different sowing methods mainly promote the accumulation of nitrogen in grains by 
promoting the operation of nitrogen accumulation before flowering, especially the wide sowing.

Table 4. Effects of different sowing method on pre-anthesis accumulated nitrogen translocation and nitrogen accumulation amount after flowering of winter wheat

\begin{tabular}{c|c|c|c|c}
\hline \multirow{2}{*}{ Sowing method } & \multicolumn{2}{|c|}{ PANT } & \multicolumn{2}{c}{ NAAA } \\
\cline { 2 - 5 } & $\begin{array}{c}\text { Amount } \\
\left(\mathbf{k g} \cdot \mathbf{h m}^{-2}\right)\end{array}$ & $\begin{array}{c}\text { Contribution to N } \\
\text { in grains (\%) }\end{array}$ & $\begin{array}{c}\text { Amount } \\
\left(\mathbf{k g} \cdot \mathbf{h m}^{-2}\right)\end{array}$ & $\begin{array}{c}\text { Contribution to N } \\
\text { in grains (\%) }\end{array}$ \\
\hline $2017-2018$ & & & & \\
WSS & $150.12_{\mathrm{a}}$ & $81.04_{\mathrm{a}}$ & $35.18_{\mathrm{b}}$ & $19.00_{\mathrm{c}}$ \\
FS & $128.96_{\mathrm{b}}$ & $76.27_{\mathrm{b}}$ & $39.69_{\mathrm{a}}$ & $23.37_{\mathrm{b}}$ \\
DS & $110.80_{\mathrm{d}}$ & $73.52_{\mathrm{c}}$ & $40.10_{\mathrm{a}}$ & $26.60_{\mathrm{a}}$ \\
\hline $2018-2019$ & & & & \\
WSS & $117.16_{\mathrm{a}}$ & $69.03_{\mathrm{b}}$ & $49.10_{\mathrm{a}}$ & $28.97_{\mathrm{a}}$ \\
FS & $96.97_{\mathrm{c}}$ & $68.07_{\mathrm{b}}$ & $42.35_{\mathrm{b}}$ & $29.93_{\mathrm{a}}$ \\
DS & $67.26_{\mathrm{d}}$ & $68.97_{\mathrm{b}}$ & $27.94_{\mathrm{c}}$ & $29.03_{\mathrm{a}}$ \\
\hline
\end{tabular}

PANT, Pre-anthesis accumulated nitrogen translocation amount from vegetative organs to grains after anthesis: NAAA, Nitrogen accumulation amount after anthesis

\section{Effects on nitrogen use efficiency of winter wheat}

Nitrogen use efficiency can be seen from Table 5. Compared with DS in 2017-2018 the nitrogen absorption efficiency of WSS and DS was significantly improved by $50 \%$, $28 \%$ and $38 \%$ and the production efficiency of nitrogen fertilizer was significantly improved by $51 \%, 20 \%$ and $36 \%$, respectively. The nitrogen utilization efficiency of WSS and $D S$ was higher than that of drill, but the difference was not significant and the nitrogen utilization efficiency of $F S$ and $D S$ was significantly lower than that of $D S$. The yield index of nitrogen was the highest in wide and drill, but not significantly different from that in $F S$ and $D S$ the yield index of drill was the lowest. Different sowing methods can improve nitrogen absorption efficiency, nitrogen fertilizer production efficiency and nitrogen harvest index, among which WS is better. 2018-2019 nitrogen absorption efficiency and nitrogen production efficiency were significantly improved under WSS treatments compared with drill, among which nitrogen absorption efficiency was increased by $21 \%, 12 \%$ and $7 \%$, and nitrogen production efficiency was increased by $15 \%, 9 \%$ and $2 \%$, respectively. Moreover, there were significant differences among different sowing treatments. The nitrogen utilization efficiency of WSS, DS, FS and DS was significantly lower than that of drill. Different sowing methods are beneficial to the improvement of nitrogen absorption efficiency and nitrogen production efficiency, especially the wide sowing is the best.

\section{Effects on protein and component contents in mature grains of winter wheat}

Component contents in mature grains (Table 6) shows that compared with drilling, wide furrow sowing and information processing of grain of albumin, gliadin and glutelin, total protein content and protein yield increased significantly in 2017-2018, improved the grain albumin respectively $13 \%, 9 \%, 5 \%, 14 \%, 4 \%, 4 \%$ alcohol soluble protein, gluten $17 \%, 5 \%, 6 \%$ and the grain total protein were $14 \%, 4 \%, 2 \%$, valley/alcohol ratio 
increased by $3 \%, 1 \%$ and $2 \%$ respectively, but no significant difference was observed between the groups. Compared with drill, the content of globulin in seeds increased under wide and drill, but decreased under furrow and drill. It can be seen that different sowing methods are beneficial to increase the content of protein and components in grains, among which, the content of protein and components in grains and the grain/alcohol ratio are the highest under wide space sowing 2018-2019 that compared with drilling, WSS and FS and information processing, the mature grain protein content and the content of albumin, gliadin glutelin and protein yield were improved, wide globulin increased under drilling and furrow sowing processing, protein content increased by $13 \%, 15 \%$ and $4 \%$ respectively, protein yield increased by $42 \%, 35 \%$ and $16 \%$ respectively and significant difference was observed between the sowing methods. The content of protein, globulin, gliadin and gluten in grains was the highest in furrow sowing, while the yield of albumin and grain protein was the highest in wide space sowing.

Table 5. Effects of different sowing method on nitrogen use efficiency of winter wheat

\begin{tabular}{c|c|c|c}
\hline Sowing method & $\begin{array}{c}\mathbf{N} \text { uptake efficiency } \\
\left(\mathbf{k g} \cdot \mathbf{k g}^{-\mathbf{1}}\right)\end{array}$ & $\begin{array}{c}\mathbf{N} \text { use efficiency } \\
\mathbf{( k g \cdot \mathbf { k g } ^ { - 1 } )}\end{array}$ & $\begin{array}{c}\mathbf{N} \text { productive efficiency } \\
\left(\mathbf{k g} \cdot \mathbf{k g}^{-\mathbf{1}}\right)\end{array}$ \\
\hline $2017-2018$ & & & \\
WSS & $1.09_{\mathrm{a}}$ & $40.37_{\mathrm{a}}$ & $44.70_{\mathrm{a}}$ \\
FS & $0.93_{\mathrm{c}}$ & $36.73_{\mathrm{c}}$ & $35.45_{\mathrm{c}}$ \\
DS & $0.73_{\mathrm{d}}$ & $40.20_{\mathrm{a}}$ & $29.62_{\mathrm{d}}$ \\
\hline $2018-2019$ & & & \\
WSS & $1.23_{\mathrm{a}}$ & $40.11_{\mathrm{b}}$ & $50.34_{\mathrm{a}}$ \\
FS & $1.15_{\mathrm{b}}$ & $40.69_{\mathrm{b}}$ & $47.58_{\mathrm{b}}$ \\
DS & $1.02_{\mathrm{d}}$ & $43.64_{\mathrm{a}}$ & $43.65_{\mathrm{d}}$ \\
\hline
\end{tabular}

Wide space sowing (WSS): 2BMF-12/6, tillage, auto-fertilization line space: wide line space: 20-25, sub-soiling, rotary tillage

Furrow sowing (FS): 2BMFD-17/14 multipurpose, no-till, auto-fertilization farrow line space: $10-12 \mathrm{~cm}$ no tillage

Drill sowing (DS): 2BXF-12Seed driller, Nonghaha company, no-till, auto-fertilization line space: 20 $\mathrm{cm}$ no tillage

Table 6. Effects of different sowing method on grain protein and component contents for winter wheat

\begin{tabular}{c|c|c|c|c|c|c|c}
\hline $\begin{array}{c}\text { Sowing } \\
\text { method }\end{array}$ & $\begin{array}{c}\text { Albumin } \\
(\boldsymbol{\%})\end{array}$ & $\begin{array}{c}\text { Globulin } \\
(\boldsymbol{\%})\end{array}$ & $\begin{array}{c}\text { Gliadin } \\
(\boldsymbol{\%})\end{array}$ & $\begin{array}{c}\text { Glutenin } \\
(\boldsymbol{\%})\end{array}$ & Glu/Gli & $\begin{array}{c}\text { Protein } \\
\text { content }(\boldsymbol{\%})\end{array}$ & $\begin{array}{c}\text { Protein yield } \\
\left(\mathbf{k g} \cdot \mathbf{h m}^{-2}\right)\end{array}$ \\
\hline $2017-2018$ & & & & & & & \\
WSS & $2.15_{\mathrm{a}}$ & $1.96_{\mathrm{a}}$ & $4.07_{\mathrm{a}}$ & $4.74_{\mathrm{a}}$ & $1.17_{\mathrm{a}}$ & $14.14_{\mathrm{a}}$ & $1159.98_{\mathrm{a}}$ \\
FS & $2.09_{\mathrm{b}}$ & $1.78_{\mathrm{b}}$ & $3.70_{\mathrm{b}}$ & $4.25_{\mathrm{b}}$ & $1.15_{\mathrm{a}}$ & $12.89_{\mathrm{b}}$ & $831.09_{\mathrm{c}}$ \\
DS & $1.91_{\mathrm{d}}$ & $1.79_{\mathrm{b}}$ & $3.57_{\mathrm{c}}$ & $4.06_{\mathrm{c}}$ & $1.14_{\mathrm{a}}$ & $12.37_{\mathrm{c}}$ & $652.78_{\mathrm{d}}$ \\
\hline $2018-2019$ & & & & & & & \\
WSS & $2.27 \mathrm{a}$ & $1.87_{\mathrm{ab}}$ & $4.18_{\mathrm{a}}$ & $4.83_{\mathrm{a}}$ & $1.15_{\mathrm{a}}$ & $14.18_{\mathrm{b}}$ & $1297.97 \mathrm{a}$ \\
FS & $2.25_{\mathrm{a}}$ & $2.00_{\mathrm{a}}$ & $4.25_{\mathrm{a}}$ & $4.84_{\mathrm{a}}$ & $1.14_{\mathrm{a}}$ & $14.43_{\mathrm{a}}$ & $1235.03_{\mathrm{b}}$ \\
DS & $1.93_{\mathrm{a}}$ & $1.82_{\mathrm{ab}}$ & $3.52_{\mathrm{b}}$ & $4.11_{\mathrm{b}}$ & $1.17_{\mathrm{a}}$ & $12.54_{\mathrm{d}}$ & $917.20_{\mathrm{d}}$ \\
\hline
\end{tabular}




\section{Discussion}

The Loess Plateau in China covers about 0.65 million $\mathrm{km}^{2}$ area and has a 108 million population (Wang et al., 2010). The Loess Plateau has a semiarid climate with low and variable rainfall from 300-700 $\mathrm{mm}$ ( $\mathrm{Li}$ et al., 1992). Despite this productivity, precipitation can be unpredictable and insufficient for the winter wheat crop. Water is the most important limiting factor in wheat production (Zhang et al., 1999). For winter wheat, yield and biomass are dependent on water availability (Kang et al., 2002a). Irrigation is often required for augmentation of rainfall, especially during the drier winter and spring months, though this practice often exerts harmful environmental effects including drops in the water table and an associated reduction of groundwater supplies (Li et al., 2008). Some previous research also indicated that water stored at sowing time may be an important complement to the seasonal rains in dryland areas since this stored water may be more effective in promoting yield (Sun et al., 2010).

\section{Effect of different sowing methods on soil water consumption and yield characteristics}

For dryland wheat it is very important to form strong seedlings before winter and ensure safe wintering. Sowing quantity directly regulates population size, affects stability of population growth and stability of individual growth and then determines the final panicle number (Troccoli et al., 2005). Sowing methods should be combined with other cultivation measures, such as irrigation. Ridge making and furrow sowing mainly affect the surface shape and concentrate water in the trench. On the one hand, surface runoff is regulated to increase infiltration on the other hand, irrigation water can be reduced. As an effective water-saving seeding method, it has been widely used at home and abroad. Wiyo et al. (1999) showed that on the basis of conventional irrigation, the water use efficiency could be improved by reducing the irrigation amount by $30 \%$ without affecting the growth and development of wheat (Lu et al., 2003). Furrow sowing could change the flow direction and speed of surface runoff, promote water infiltration, and thus promote water absorption by roots. Many studies at home and abroad on the yield-increasing mechanism of furrow sowing show that, to a certain extent, furrow sowing eliminates many negative impact factors of traditional sowing method, improves the internal light, temperature, water and microbial environment of soil and creates suitable environmental conditions for wheat growth, thereby promoting the growth and development of wheat (Randall et al., 1990). Wheat is a crop that requires a lot of water. Water is an important factor affecting wheat production. The water saving effects of different farming and sowing methods are also different (Raun et al., 2002). Wheat yield in semiarid dryland areas is highly affected by the variation in the amount and distribution of seasonal precipitation (Wang et al., 2015). Precipitation is an important meteorological factor which affect soil water content. In the Loess Plateau and other dryland areas, the soil water content at time of sowing is important for early growth of wheat and highly dependent on the precipitation during fallow season of dryland wheat (Kang et al., 2002b; Rossato et al., 2017). The wheat yield is linearly related to the soil water content (Musick et al., 1994; Qin et al., 2013). The use of wide range precision sowing method under the condition of corn straw mulch significantly improved reduced production and composition (Liu et al., 2015). The soil water storage capacity of 0-300 $\mathrm{cm}$ soil layer with full membrane soil hole sowing increased during 
sowing jointing and grouting and the water consumption intensity increased during sowing jointing water use efficiency increases (Hou et al., 2017).

This study shows that compared with drill sowing (DS), wide space sowing (WSS) and furrow sowing (FS) can significantly increase water consumption during the growing period water storage and water consumption ratio significantly reduce the water consumption ratio of precipitation and irrigation water consumption. The effect is better and the percentage of soil water consumption in the $0-200 \mathrm{~cm}$ soil layer under wide sowing is significantly higher than in other sowing methods and the water consumption during the growth period under wide space sowing increased. The increase of $17 \%$ and $33 \%$ may be due to the uneven distribution of the roots in the upper layer of drill sowing (DS). This caused the soil moisture to be lost in the manner of soil evaporation. The water consumption of the plant increases and the ineffective water consumption decreases which is beneficial to the growth and development of wheat. The individual growth and nutrient movement of wheat during the whole growth period has a very important influence on the formation of grain yield (Chu et al., 2018). Nitrogen absorption efficiency, nitrogen fertilizer production efficiency and nitrogen harvest index significantly improved, but the mechanism that affects nitrogen operation by wide space sowing needs further study. The number of spikes, grains per spike and thousand grain weight are the three elements of yield formation. Su et al. (2007) and Dang et al. (2015) showed that compared with the traditional sowing method, the use of wide sowing increased the number of ears by $5 \%$, the weight per thousand by $3 \%$, and the yield increased by $12 \%$. The number of ears and yield showed a very significant positive correlation. There was a significant positive correlation between ears number and thousand-grain weight and yield. It can be seen that WSS mainly increased yield by increasing ear number which is the same as that of Li et al. (2012). The yield is significantly positively related to the water consumption during the growth period and the nitrogen accumulation before flowering. WSS has high water consumption during the growth period and high nitrogen before bloom which promotes nutrient absorption and operation and increases yield. In addition, the broad soiled sowing population structure is reasonable, significantly increasing the number of tillers in the middle and late stages of reproductive growth, increasing ear length. The accumulation of dry matter is conducive to the increase of yield. Different sowing models have their own characteristics and only by supporting different seeding rates according to different seeding models can it be more beneficial to increase wheat yield (Sweeney et al., 2000). Studies by Wang et al. (2016) showed that in the wheat cotton intercropping mode the DS technique should be used and the seeding rate should be controlled at 225.0$262.5 \mathrm{~kg} \cdot \mathrm{hm}^{-2}$. It is most beneficial to improve wheat yield (Zhang et al., 2012). The precision DS method the sowing spring wheat can sow $525 \mathrm{~kg} \cdot \mathrm{hm}^{-2}$ and can reach a high yield of $9499.5 \mathrm{~kg} \cdot \mathrm{hm}^{-2}$. Liu et al. (2012) found in the study of dry land wheat that the sowing amount in open field was $354 \times 104 \mathrm{hm}^{-2}$, and $245 \times 104 \mathrm{hm}^{-2}$ on the film was good for improving grain yield (Feng et al., 2013), Research showed that the suitable seeding rate for wide space sowing is $105 \mathrm{~kg} \cdot \mathrm{hm}^{-2}$. At this time, the highest yield of wheat is $13 \%$ higher than that of conventional precision sowing and the highest yield was $8643 \mathrm{~kg} \cdot \mathrm{hm}^{-2}$ Cao et al. (2018). In this experiment the interaction effects of the sowing method and the sowing amount were analyzed the sowing method the sowing amount the sowing method $\times$ the sowing amount had a significant effect on the number of ears grain number, and thousand-grain weight yield of winter wheat. The suitable sowing capacity for WSS is $300 \mathrm{~kg} \cdot \mathrm{hm}^{-2}$, the yield at this seeding amount is 
$7158 \mathrm{~kg} \cdot \mathrm{hm}^{-2}$ and the suitable seeding capacity for trenching is $300 \mathrm{~kg} \cdot \mathrm{hm}^{-2}$. The suitable sowing capacity for DS is $225 \mathrm{~kg} \cdot \mathrm{hm}^{-2}$, the yield at this sowing capacity is 5832 $\mathrm{kg} \cdot \mathrm{hm}^{-2}$. It can be seen that the appropriate seeding amount should be selected according to different seeding methods. Under this experimental condition, the matching sowing method of WSS is $300 \mathrm{~kg} \cdot \mathrm{hm}^{-2}$, which is conducive to the improvement of grain yield. It is suitable for the local sowing method and volume.

\section{Effect of different sowing methods on quality nitrogen use efficiency formation}

Agronomic practices need to ensure optimal $\mathrm{N}$ fertilization. These are conducted when the plant can still incorporate the $\mathrm{N}$ into its grain and does not limit NUE. The protein change in response to $\mathrm{N}$ and late-season application time of $\mathrm{N}$ is generally greater and more reliable under irrigation than dryland production, because the $\mathrm{N}$ is usually incorporated with irrigation, which increase $\mathrm{N}$ uptake (Jones et al., 2012). There is a coupling effect between water and nitrogen fertilizer operation in agricultural production and the reasonable combination of water and nitrogen has a significant effect of increasing yield. On the one hand, the law of soil water transport and accumulation and consumption affects the absorption and utilization of $\mathrm{N}$ elements by crops (Yang et al., 2008). On the other hand, proper application of $\mathrm{N}$ fertilizer can, to a certain extent, make up for the material loss caused by soil deficit. Jia et al. (1995) showed that compared with drill sowing wide space sowing can improve nitrogen accumulation nitrogen absorption and nitrogen utilization efficiency, the yield and nitrogen accumulation were significantly positive. There was a significant negative correlation between nitrogen accumulation and nitrogen use efficiency, a significant positive correlation was observed between nitrogen absorption efficiency and nitrogen use efficiency. This study shows that wide space sowing can significantly increase plant nitrogen accumulation at various growth stages and the contribution rate to grains is mainly increased by the amount of nitrogen before flowering, which is consistent with previous research results (Xue et al., 2017). Moderate drought is conducive to increasing the protein content of grains and is beneficial to increase the grain, alcohol ratio, while too much water will reduce the grain protein content (Xu et al., 2003; Zhou et al., 2006). But the heavy application of $\mathrm{N}$ fertilizer represents a significant cost and also cause serious environmental problems due to the loss of a large amount of applied $\mathrm{N}$ into the environment (Ma et al., 2019). Optimizing the input of $\mathrm{N}$ is difficult under rain-fed cropping system due to the highly variable weather and rainfall. Less $\mathrm{N}$ supply may limit grain yield and grain protein content and excessive application of $\mathrm{N}$ may increase water use in the early growing season leading to water deficit stress during flowering and grain filling, resulting in poor grain set (He et al., 2014). The relative water content of wheat in the grain filling stage was in the range of $50 \%-80 \%$. With the increase of soil moisture the protein content of grains showed a gradual decline Zhang et al., 2006 carried out potted test results. It was shown that the soil moisture content during the whole growth period was within the range of $50 \%$ to $80 \%$ of the maximum water holding capacity in the field. As the soil moisture increased the protein content of the grains gradually decreased. Under the conditions of this test, the water content in the growing period showed a significant positive correlation with the protein content of the grains. The wide space sowing had high water consumption in the growing period, high grain protein content and high grain/alcohol ratio (Zhang et al., 2014). Research showed that the use of wide stubble sowing can make wheat individuals grow robustly which can significantly increase the bulk density and 
hardness of wheat grains significantly improve water absorption wet gluten content and sedimentation value and significantly increase the maximum resistance of dough, the standard value of power and flour quality, but has no significant effect on flour protein content and dough ductility (Wang et al., 2012). Some studies have shown that the amount of nitrogen before flowering affects wheat grain protein content. It has a large regulatory effect (Desai et al., 1978) and some studies have shown that the contribution of nitrogen accumulation and operation amount before and after flowering to grain protein varies from species to species. The protein content has a regulating effect and the nitrogen accumulation after flowering mainly has a regulating effect on the grain protein content in medium protein varieties. There was a significant positive correlation between protein content in grains and nitrogen accumulation before flowering, and a significant or very significant positive correlation with grain/alcohol ratio, wet gluten content, water absorption and quality of powder maps. The grain/alcohol ratio is an important index for evaluating the quality of wheat (Zou et al., 2006). The grain alcohol ratio is related to water consumption during growth, nitrogen accumulation before flowering, wet gluten content, water absorption, dough formation time and flour. There is a significant or very significant positive correlation between the mass numbers in the prime image. It can be seen that increasing the water consumption during the growth period and the amount of nitrogen accumulation before flowering are conducive to increasing the protein content of the grain, increasing the grain/alcohol ratio, and ultimately facilitating the formation of quality. Under this test condition, the use of wide space sowing is the most beneficial to improve the grain quality indicators such as protein and component content, grain, alcohol ratio, wet gluten content, water absorption, dough formation time and stabilization time.

\section{Effect of different sowing methods on yield and quality}

Studies have shown that if the local conventional sowing amount is increased by $10 \%-20 \%$, the yield and quality can be increased by $2-15 \%$. Gaju et al., 2011 showed that an appropriate increase in sowing amount could promote wheat root binding, increase in deep roots, enhance the absorption and transport function of roots and thus enhance the absorption and utilization capacity of nitrogen. Blankenau et al. (2001) believed that appropriate sowing amount could promote wheat nitrogen consumption (Gao et al., 2009). Constructing a reasonable population structure is that individuals can fully absorb water, light, heat and nutrient resources, promote the healthy growth of individuals, coordinate the contradictions between individuals, groups and extremely important for the coordination of wheat yield and quality (Bhatta et al., 2017); Lin et al. (1996). Too much sowing more tillers in the group leads to more water consumption in the early stages of development, drought intensification in the later stages and lower yields; too little sowing, fewer tillers in the groups, insufficient panicles and lower yields (Lei et al.,2017; Shi et al.,2017). Appropriate sowing amount can optimize yield components and increase yield. Hai et al. (2002) showed that Xiaoyan 503 was in the range of $75 \mathrm{~kg} \mathrm{hm}^{-2}$ to $165 \mathrm{~kg} \mathrm{hm}^{-2}$ and the yield increased first and then decreased with the increase of seeding amount and it was the highest at $105 \mathrm{~kg} \mathrm{hm}^{-2}$ (Liu et al., 2017). According to them with the increased seeding volume, the leaf area index of Guomai 301 in the flowering stage gradually increased, the dry matter accumulation in the flowering stage increased first and then decreased and the number of ears and yield increased first and then decreased. Under the conditions of this experiment, the relevant analysis of factors related to yield formation shows that the water consumption during 
the growth period, the number of ears, the 1000 grain weight and the yield have a significant or very significant correlation and the seeding rate is $300 \mathrm{~kg} \cdot \mathrm{hm}^{-2}$. In the period the water consumption and the proportion of stored water consumption increased and the water consumption and irrigation water consumption decreased and the output gradually increased with the increase of the sowing amount. $300 \mathrm{~kg} \cdot \mathrm{hm}^{-2}$ was the highest output and the water use efficiency increased. Increasing the sowing volume within a certain range increased the nitrogen accumulation in the above ground, the nitrogen utilization efficiency decreased and the nitrogen utilization increased first and then decreased (Tao et al., 2018). A research by Shuli et al. (2012) showed that increasing planting density within a certain range increased nitrogen accumulation and absorption efficiency in the above-ground area and reduced nitrogen use efficiency. Wang et al. (2012) showed that with the increase of planting density, the nitrogen harvest index, grain increased but accumulation and nitrogen content gradually decreased, and the contribution rate of nitrogen transport from vegetative organs to the grain during the flowering period showed an upward trend. Plant nitrogen accumulation wave, nitrogen absorption and utilization rate and nitrogen fertilizer partial production efficiency showed a trend of rising first and then decreasing (Xue et al., 2017). In the range of $245 \sim 330 \times 104 \mathrm{hm}^{-2}$, the grain protein content increased first and then decreased with increasing planting density. Under the conditions of this test a correlation analysis was performed and the protein content was extremely significantly positively correlated with the nitrogen accumulation and the grain/alcohol ratio before flowering. The change trend of first increase and then decrease reached the highest at $300 \mathrm{~kg} \cdot \mathrm{hm}^{-2}$, (Wang et al., 2014). The increasing sowing amount increased the amount of nitrogen accumulation in various organs before flowering and the contribution of nitrogen accumulation in leaves glumes and cobs to flowering increased before flowering. This study showed that with the increase of seeding rate the nitrogen accumulation of plants in each growth stage showed a trend of first increase and then decline in the contribution rate of nitrogen accumulation before flowering and the amount of nitrogen accumulation before flowering showed first contributions to grains. After the increased the nitrogen absorption efficiency, nitrogen fertilizer production efficiency increased first and then decreased. It reached the highest at $300 \mathrm{~kg} \cdot \mathrm{hm}^{-2}$. It can be seen that when the wide space sowing rate is $300 \mathrm{~kg} \cdot \mathrm{hm}^{-2}$, it is beneficial to improve accumulation of nitrogen in each growth period, to increase the contribution rate of nitrogen operation before flowering with grain, and to improve nitrogen absorption efficiency.

\section{Conclusion}

Our study showed that the different sowing methods: wide space sowing (WSS), furrow sowing (FS) and drill sowing (DS) and four nitrogen level $\left(150 \mathrm{~kg} \cdot \mathrm{hm}^{-1}\right.$, $225 \mathrm{~kg} \cdot \mathrm{hm}^{-1}, 300 \mathrm{~kg} \cdot \mathrm{hm}^{-1}$ and $375 \mathrm{~kg} \cdot \mathrm{hm}^{-1}$ ) have different effects on the yield and quality. Wide space sowing (WSS) in Wenxi area was beneficial to the growth and development of winter wheat, improving nitrogen uptake at different growing stage, ultimately increasing yield and improving quality. Although increasing nitrogen accumulation in each growing period and improving flowering. Plant height decreased the tiller amount of winter wheat at anthesis. In summary, the wide space sowing and nitrogen level of $300 \mathrm{~kg} \cdot \mathrm{hm}^{-1}$ was beneficial to increase water consumption during the growth period, increase the tiller dynamics, promote nutrient operation, increase yield 
and grain protein content, it was beneficial to improve accumulation of nitrogen in each growth period, increase the contribution rate of nitrogen operation before flowering with grain, improve nitrogen absorption efficiency and nitrogen fertilizer production efficiency was beneficial to plant nutrient operation.

Acknowledgements. "Modern Agriculture Industry Technology System Construction” (No. CARS-3124); The National Key Research and Development Program of China (No. 2018YFD020040105); The Sanjin Scholar Support Special Funds Projects; National Natural Science Foundation of China (No. 31771727); The "1331" Engineering Key Innovation Cultivation Team-Organic Dry Cultivation and Cultivation Physiology Innovation Team (No. SXYBKY201733).

\section{REFERENCES}

[1] Ahmadzai, M. A., Cai, M., Meng, Y., Zhou, J. B. (2017): Effects of water saving practices on winter wheat a summer maize yields in south Loess Plateau of Northwest China. - Agrotechnology 6: 157.

[2] Bhatta, M., Eskridge, K. M., Rose, D. J. (2017): Seeding rate, genotype, and topdressed nitrogen effects on yield and agronomic characteristics of winter wheat. - Crop Science 57(2): 951-963.

[3] Blankenau, K., Olfs, H. W. (2001): Effect of different crop densities of winter wheat on recovery of nitrogen in crop and soil within the growth period. - Journal of Agronomy and Crop Science 186(3): 151-156.

[4] Cao, J., Zhang, J. (2018): Effects of different sowing rates on wheat yield in trench trenches. - Grassroots Agricultural Technology Extension 6(06): 22-23.

[5] Chu, J., Zhu, W., Yin, L. (2018): Effects of wide-seeding on winter wheat 'Tainong 18' yield and nitrogen use efficiency. - Chinese Journal of Applied Ecology 29(08): 25172524.

[6] Dang, W., Ma, C., Zhao, Q. (2015): Effect of wide-range precision seeding on wheat yield and yield components. - Hebei Agricultural Sciences 19(02): 15-17.

[7] Desai, R. M., Bhatia, C. R. (1978): Nitrogen uptake and nitrogen harvest index in durum wheat cultivars varying in their grain protein concentration. - Euphytica 27(2): 561-566.

[8] Dong, S., Sun, M., Gao, Z., Xue, L., Lei, M., Hou, C. (2018): Effects of sowing methods on nitrogen utilization and yield of dryland wheat. - Journal of Shanxi Agricultural Sciences 46(2): 207-210.

[9] Feng, C. N., Guo, W. S., Wang, F. T., Zhu, X. K., Peng, Y. X. (1999): Mechanism of the population formation with high grain-leaf ratio in wheat. - Scientia Agricultura Sinica 32(6): 47-55.

[10] Feng, R., Guo, A., Zhu, X. (2013): Effects of different wide-seeded wheat sowing on population dynamics and yield. - Journal of Henan University of Science and Technology (Natural Science Edition) 41(02): 6-8.

[11] Fu, Q., Wang, Q., Shen, X., Fan, J. (2014): Optimizing water and nitrogen inputs for winter wheat cropping system on the Loess Plateau, China. - Journal of Arid Land 6(2): 230-242.

[12] Gaju, O., Allard, V., Martre, P. (2011): dentification of traits to improve the nitrogen-use efficiency of wheat genotypes. - Field Crops Research 123(2): 139-152.

[13] Gao, Y. J., Li, Y., Zhang, J. C. (2009): Effects of mulch, N fertilizer, and plant density on wheat yield, wheat nitrogen uptake, and residual soil nitrate in a dryland area of China. Nutr Cycl Agroecosyst 85: 109-121.

[14] Gonzalez Dugo, V., Durand, J. L., Gastal, F. (2010): Water deficit and nitrogen nutrition of crops. A review. - Agron. Sustain. Dev. 30: 529-544. 
[15] Grigoras, M. A., Popescu, A., Pamfil, D., Has, I., Gidea, M. (2012): Influence of notillage agriculture system and fertilization on wheat yield and grain protein and gluten contents. - Journal of Food, Agriculture and Environment 10(2): 539Article 852.

[16] Guo, Z., Zhang, Y., Zhao, J., Shi, Y., Yu, Z. (2014): Nitrogen use by winter wheat and changes in soil nitrate nitrogen levels with supplemental irrigation based on measurement of moisture content in various soil layers. - Field Crops Res. 164: 117-125.

[17] Hai, J., You, H., Zhang, B. (2002): Effects of different sowing rates on the growth, yield and quality of noodle special wheat variety Xiaoyan503. - Journal of Triticeae Crops 22(3): 92-94.

[18] He, L., Cleverly, J., Chen, C., Yang, X., Li, J., Liu, W., Yu, Q. (2014): Diverse responses of winter wheat yield and water use to climate change and variability on the semiarid Loess Plateau in China. - Agronomy Journal 106(4): 1169-1178.

[19] Hou, H., Gao, S., Zhang, X. (2017): Water consumption characteristics of spring wheat in full-membrane soil cultivation in dry land and its effect on yield. - Journal of Soil and Water Conservation 31(01): 202-210.

[20] Jia, S. L., Meng, C. X., Tang, Y. X., Liu, C. T. (1995): Effects of water stress on wheat yield and the characteristic of nutrient absorption. - Chinese Journal of Soil Science 26(1): 6-8.

[21] Jones, C., Olson-Rutz, K. (2012): Practices to Increase Wheat Grain Protein. - Montana State University Extension, Montana State University, Bozeman.

[22] Kang, S., Zhang, L., Liang, Y., Hu, X., Cai, H., Gu, B. (2002a): Effects of limited irrigation on yield and water use efficiency of winter wheat in the Loess Plateau of China. - Agric. Water Manag. 55: 203-216.

[23] Kang, S., Zhang, L., Liang, Y., Dawes, W. R. (2002b): Simulation of Winter Wheat Yield and Water Use Efficiency on the Loess Plateau of China Using WAVES. - In: McVicar, T. R., Rui, L., Walker, J., Fitzpatrick, R. W., Changming, L. (eds.) Regional Water and Soil Assessment for Managing Sustainable Agriculture in China and Australia. ACIAR Monograph No. 84. Australian Centre for International Agricultural Research, Bruce, pp. 95-104.

[24] Yadav, A., Sheoran, P., Singh, S. (2011): Effect of sowing methods and nitrogen management strategies on yield and nutrients uptake of wheat (Triticum aestivum, L.). Ecology, Environment and Conservation 17(4): 665-668.

[25] Lei, M., Sun, M., Gao, Z. (2017): The effect of water-soaked and suitable seeding in dry season on wheat yield in dryland. - Chinese Agricultural Science 50(15): 2904-2915.

[26] Li, G., Shi, Y. (2012): Effects of subsoil and tillage on post-anthesis root senescence and yield of dryland wheat. - Journal of Triticeae Crops 32(3): 500-502.

[27] Li, S., Xiao, L. (1992): Distribution and management of drylands in the People's Republic of China. - Advances in Soil Science 18: 148-293.

[28] Li, H., Xue, J.-F., Gao, Z.-Q., Xue, N.-W., Yang, Z.-P. (2018): Response of yield increase for dryland winter wheat to tillage practice during summer fallow and sowing method in the Loess Plateau of China. - J. Integr. Agric. 17: 817-825.

[29] Li, Q., Chen, Y., Liu, M., Zhou, X., Yu, S., Dong, B. (2008): Effects of irrigation and planting patterns on radiation use efficiency and yield of winter wheat in North China. Agric. Water Manag. 95 469-476.

[30] Li, R., Hou, X., Jia, Z., Han, Q., Ren, X. (2013): Effects on soil temperature, moisture, and maize yield of cultivation with ridge and furrow mulching in the rainfed area of the Loess Plateau, China. - Agric. Water Manag. 116: 101-109.

[31] Liang, Y. F., Khan, S., Ren, A. X., Lin, W., Anwar, S., Sun, M., Gao, Z. Q. (2019): Subsoiling and sowing time influence soil water content, nitrogen translocation and yield of dryland winter wheat. - Agronomy 9(1): 37.

[32] Lin, C. C., Kao, C. H. (1996): Disturbed ammonium assimilation in associated with growth inhibition of roots in rice seedlings caused by $\mathrm{NaCl}$. - Plant Growth Regulation 18(3): 233-238. 
[33] Liu, L., Zhang, S. (2012): Study on the suitable sowing dates and sowing rates of different sowing methods for dryland wheat in the southwest of Shanxi. - Wheat Research 33(02): 11-22.

[34] Liu, X., Wu, C., Ma, C. (2015): Compensation effect of yield loss and water use efficiency of wide-row precision sowing winter wheat under corn stalk cover. - Journal of Drainage and Irrigation Machinery Engin 33(09): 811-817.

[35] Liu, H., Ni, Y., Chen, Y. (2017): Effects of sowing date and amount on agronomic characteristics and yield of winter wheat Guomai 301. - Jiangsu Agricultural Sciences 45(14): 49-53.

[36] Liu, X., Wang, K., Yang, Z., Xue, J., Du, T., Zong, Y., Hao, X., Sun, M., Gao, Z. (2018): Effects of different matching sowing dates and sowing methods on agronomic characters and yield of winter wheat in dry land in two cropping years. - North China Agricultural Journal 33(2): 232-238.

[37] López-Bellido, L., Muñoz-Romero, V., Benítez-Vega, J., FernándezGarcía, P., Redondo, R., López-Bellido, R. J. (2012): Wheat response to nitrogen splitting applied to a Vertisols in different tillage systems and cropping rotations under typical Mediterranean climatic conditions. - European Journal of Agronomy 43: 24-32.

[38] Lu, D.-Q., Shao, M.-A., Wang, Q. (2003): Experimental study on soil water distribution under furrow tillage. - Chinese Journal of Soil Science (01): 147-150.

[39] Ma, G., Liu, W., Li, S., Zhang, P., Wang, C., Lu, H., Xie, Y., Ma, D., Kang, G. (2019): Determining the optimal $\mathrm{N}$ input to improve grain yield and quality in winter wheat with reduced apparent N loss in the North China Plain. - Frontiers in Plant Science 10: Article 181.

[40] Mann, C., Lynch, D., Fillmore, S., Mills, A. (2019): Relationships between field management, soil health, and microbial community composition. - Appl. Soil Ecol. 144: $12-21$.

[41] Munir, A. T., Rahman, A., Tawaha, M., (2002): Impact of seeding rate, seeding date, rate and method of phosphorus application in faba bean (Vicia faba, L.) in the absence of moisture stress. - Biotechnol. Agron. Soc. Environ. 6(3): 171-178.

[42] Musick, J. T., Jones, O. R., Stewart, B. A., Dusek, D. A. (1994): Water-yield relationships for irrigated and dryland wheat in the, U.S. Southern Plains. - Agronomy Journal 86: 980-986.

[43] Noor, H., Khan, S., Min, S., Yu, S., Ren, A. (2020a): Effect of different sowing methods and nitrogen rates on yield and quality of winter wheat in Loess Plateau of China. Applied Ecology and Environmental Research 18(4): 5701-5726.

[44] Noor, H., Min, S., Ren, A., Lin, W. (2020b): Effect of seeding rate on soil water consumption yield and quality under wide space sowing of dryland winter wheat on the loess plateau, China. - Applied Ecology and Environmental Research 18(5):7167-7188.

[45] Parry, M. A. J., Reynolds, M., Salvucci, M. E., Raines, C., Andralojc, P. J., Zhu, X. G., Price, G. D., Condon, A. G., Furbank, R. T. (2011): Raising yield potential of wheat. II. Increasing photosynthetic capacity and efficiency - J. Exp. Bot. 62 453-467.

[46] Qin, W., Chi, B., Oenema, O. (2013): Long-term monitoring of rainfed wheat yield and soil water at the loess plateau reveals low water use efficiency. - PLoS One 8(11): e78828.

[47] Randall, C. R. (1990): Extension programs and farmer experiences with ridge tillage. Soil \& Tillage Research, (18); 283-293.

[48] Raun, W. R., Solie, J. B., Johnson, G. V., Stone, M. L., Mullen, R. W., Freeman, K. W., Thomason, W. E., Lukina, E. V. (2002): Improving nitrogen-use efficiency in cereal grain production with optical sensing and variable rate application. - Agronomy Journal 94: 351-815.

[49] Ren, A. X., Sun, M., Xue, L. Z., Deng, Y. (2019): Spatio-temporal dynamics in soil water storage reveals effects of nitrogen inputs on soil water consumption at different growth stages of winter wheat. - Agricultural Water Management 216: 379-389. 
[50] Roelcke, M. (1994): Die Ammoniac Volatilization nach Ausbringung von Mineraldünger Stickstoff in carbonatreichen chinesischen Löss-Ackerböden. - In: Göttinger Beiträge zur Land- und Forstwirtschaft in den Tropen und Subtropen. Volume 92. Verlag Erich Goltze, Göttingen.

[51] Rossato, L., Alvalá, R. C., Marengo, J. A., Zeri, M., Cunha, A. P., Pires, L., Barbosa, H. A. (2017): Impact of soil moisture on crop yields over Brazilian semiarid. - Frontiers in Environmental Science 5: Article 73.

[52] Schlegel, A. J., Assefa, Y., Haag, L. A., Thompson, C. R., Holman, J. D., Stone, L. R. (2017): Yield and soil water in three dryland wheat and grain sorghum rotations. Agronomy Journal 109(1): 227-238.

[53] Shi, X. F., Chou, S. Y., Shi, Z. L. (2017): Effect of sowing date and sowing amount on population traits and yield of winter wheat cultivar Yaomai 16. - Journal of Triticeae Crops 37(2): 1-9.

[54] Shuli, H. M., Dai, X. (2012): Effects of planting density on nitrogen absorption and distribution in winter wheat. - Chinese Journal of Eco-Agriculture 20(10): 1276-1281.

[55] Su, Z. Y., Zhang, J. S., Wu, W. L. (2007): Effects of conservation tillage practices on winter wheat water use efficiency and crop yield on Loess Plateau, China. - Agricultural Water Management 87(3): 307-314.

[56] Sun, J., Zou, X., Gao, Q., Jia, B., Yang, X. (2010): Natural Background of China's Drylands. - In: Ci, L., Yang, X. (eds.) Desertification and Its Control in China. Springer, Berlin, pp. 29-99.

[57] Sun, M., Ge, X. M., Gao, Z. Q., Ren, A. X., Deng, Y., Zhao, W. F., Zhao, H. M. (2014): Relationship between water storage conservation in fallow period and grains protein formation in dryland wheat in different precipitation years. - Scientia Agriculture Sinica 47(9): 1692-1704 (in Chinese).

[58] Sun, M., Deng, Y., Gao, Z. Q., Zhao, H. M., Ren, A. X., Li, G. (2015): Effects of tillage in fallow period and sowing methods on water storage and grain protein accumulation of dryland wheat. - Pakistan, J. Agric. Sci. 52: 1-8.

[59] Sweeney, D. W., Granade, G. V., Eversmeyer, M. G. (2000): Phosphorus, potassium, chloride, and fungicide effects on wheat yield and leaf rust severity. - Journal of Plant Nutrition 23(9): 1267-1281.

[60] Tao, Z., Wang, D., Ma, S., Yang, Y., Zhao, G., Chang, X. (2018): Light interception and radiation use efficiency response to tridimensional uniform sowing in winter wheat. Integr. Agric. 17 566-578.

[61] Tavakkoli, A. R., Oweis, T. Y. (2004): The role of supplemental irrigation and nitrogen in producing bread wheat in the highlands of Iran. - Agr. Water Manage. 65: 225-236.

[62] Triboi, E., Triboi-Blondel, A. M. (2002): Productivity and grain or seed composition: a new approach to an old problem: invited paper. - European Journal of Agronomy 16: 163-186.

[63] Troccoli, A., Codianni, P. (2005): Appropriate seeding rate for einkorn, emmer, and spelt grown under rainfed condition in southern Italy. - European Journal of Agronomy 22: 293-300.

[64] Wang, X. C., Li, J. (2010): Evaluation of crop yield and soil water estimates using the EPIC model for the Loess Plateau of China. - Mathematical and Computer Modelling 51(1112): 1390-1397.

[65] Wang, L. F., Shangguan, Z. P. (2015): Water use efficiency of dryland wheat in response to mulching and tillage practices on the Loess Plateau. - Scientific Reports 5: 12225.

[66] Wang, H., Yu, Z., Zhang, Y., Shi, Y., Wang, D. (2012a): Effects of tillage regimes on water consumption and dry matter accumulation in dryland wheat. - Acta Agronomica Sinica 38: 675-682.

[67] Wang, K., Zhao, H., Hu, L. (2012a): Effect of wide-range precision seeding on photosynthetic characteristics and yield of winter wheat. - Agricultural Science and Technology Newsletter 9: 60-62. 
[68] Wang, N., Wang, J., Yao, G. (2014): Yield and quality of wheat "Jiumai 2" with different sowing dates and sowing rates. - Chinese Agricultural Science Bulletin 30(21): 80-84.

[69] Wang, S., Qi, H., Wang, Y. (2016): Effects of seeding rate and seeding mode on wheat growth and development and yield under wheat-cotton intercropping mode. - Shandong Agricultural Sciences 48(7): 39-43.

[70] Wiyo, K. A., Kasomekera, Z. M., Feyen, J. (1999): Variability in ridge and furrow size and shape and maize population density on small subsistence farms in Malawi. - Soil \& Tillage Research 51: 113-119.

[71] Xu, Z. Z., Yu, Z. W., Wang, D. (2003): Effect of irrigation conditions on protein composition accumulation of grain and its quality in winter wheat. - Acta Agronomical Sinica 29(5): 682-687.

[72] Xue, L., Sun, M., Gao, Z. (2017): Effects of incremental subsurface water storage sowing of dryland wheat on plant nitrogen use and grain yield and protein formation. - China Agricultural Science 50(13): 2451-2462.

[73] Xue, L., Khan, S., Sun, M., Anwar, S., Ren, A., Gao, Z., Lin, W., Xue, J., Yang, Z., Deng, Y. (2019): Effects of tillage practices on water consumption and grain yield of dryland winter wheat under different precipitation distribution in the loess plateau of China. - Soil and Tillage Research 191: 66-74.

[74] Yan, C. P., Zhang, Y. Q., Zhang, D. Y., Dang, J. Y. (2008): Effects of sowing date and planting density on the grain's protein component and quality of strong and medium gluten winter wheat cultivars. - J. Applied. Ecol. 19(8): 1733-40.

[75] Yan, W., Deng, L., Zhong, Y., Shangguan, Z. (2015): The characters of dry soil layer on the loess plateau in china and their influencing factors. - PLoS One 10(8): e0134902.

[76] Yang, S. L., Jia, X. L., Zhang, F. L., Ma, R. K., Meng, X. F., Li, A. H. (2008): Effects of water and nitrogen coupling in winter wheat on leaves NRA, plant nitrogen absorption and yield. - Acta Agriculturae Boreali-Sinica 23(4): 124-129.

[77] Yue, J., Shao, Y., Chen, Y., Qin, F., Li, W., Jin, X. (2006): Effects of different sowing ways on the topsoil water and physiological characteristics of winter wheat. - Acta Agriculturae Boreali-Sinica 21(5): 17-19.

[78] Zhang, Z. J. (2014): Effect of Wide space sowing on the growth, yield and quality of winter wheat. - Friends of Rich Farmers 22: 144-145.

[79] Zhang, H., Wang, X., You, M., Liu, C. (1999): Water-yield relations and water-use efficiency of winter wheat in the North China Plain. - Irrig. Sci. 19: 37-45.

[80] Zhang, Y., Yang, W., Bai, J. (2006): Characteristics of synergistic changes in winter wheat yield and grain protein content and water and fertilizer regulation. - China Agricultural Sciences 39(12): 2449-2458.

[81] Zhang, S., Lovdahl, L., Grip, H., Tong, Y., Yang, X., Wang, Q. (2009): Effects of mulching and catch cropping on soil temperature, soil moisture and wheat yield on the Loess Plateau of China. - Soil \& Tillage Research 102: 78-86.

[82] Zhang, Z., Liu, G., Song, J. (2012): Experiments on seeding methods and seeding volume of spring wheat in waterland. - Gansu Agricultural Science and Technology 1: 14-16.

[83] Zhao, G. (2016): The technology of tridimensional uniform sowing in wheat, green, cost saving, high yield and high efficiency. - Farmers Sci. Technol. Train. 42-44.

[84] Zhao, M. X., Zhou, J. B., Yang, R., Zheng, X. F. (2006): Characteristics of nitrogen accumulation, distribution and translocation in winter wheat on dryland. - J. Plant Nutrition and Fertilizer Science 12: 143-149.

[85] Zou, T., Dai, T., Jiang, D. (2006): Effects of potassium levels on nitrogen accumulation and movement and grain protein formation in wheat. - China Agricultural Sciences 39(4): 686-692. 